\title{
Proses Layanan Rehabilitasi Sosial dalam Memberikan Bimbingan Karier pada Klien Binaan di Balai Rehabilitasi Sosial Bina Mandiri Palimanan Cirebon
}

\author{
Ririn Desiani Ridwan ${ }^{1}$, Jaja Suteja ${ }^{2}$ \\ ${ }^{12}$ Program Studi Bimbingan Konseling Islam, Fakultas Ushuluddin Adab dan Dakwah, \\ IAIN Syekh Nurjati Cirebon \\ Email Penulis ${ }^{1}$ : hafidzahdesiani12@gmail.com \\ Email Penulis ${ }^{2}$ : suteja.jaja83@gmail.com
}

\begin{abstract}
Abstrak
Tujuan dari penelitian ini mendeskripsikan proses layanan bimbingan karier dan hasil dari rehabilitasi sosial yang dilakukan di Bina Mandiri Palimanan Cirebon. Metode penelitian menggunakan kualitatif deskriptif. Teknik pengumpulan data berupa obervasi, wawancara, dan dokumentasi. Teknik analisis data yang digunakan melalui pengaturan data secara logis dan sistematis. Hasil penelitian ini menunjukkan pembimbingan karier dilakukan melalui tahap awal, pelaksanaan, evaluasi, dan tindak lanjut. Hasil yang tampak dari bimbingan tersebut adalah adanya perubahan dari aspek keterampilan dan semangat kerja. Perubahan itu muncul dari segi jenis keterampilan, penguasaan keterampilan, kesungguhan, dorongan semangat kerja, disiplin, tanggung jawab, produktivitas, dan kualitas kerja. Selain itu, klien binaan menjadi lebih memahami tentang potensi yang ada pada dirinya. Terutama pada hal memahami minat dan bakat yang ada pada diri klien.
\end{abstract}

Kata Kunci: Rehabilitasi Sosial; Bimbingan Karier; Klien Binaan.

\section{PENDAHULUAN}

Saat ini banyak pemuda yang hidup dan mencari nafkah di jalanan. Kehidupan mereka pun dekat dengan tindakan yang menyimpang. Fenomena tersebut dapat membuat resah dan menganggu keamanan masyarakat. Selain itu, tidak adanya pekerjaan semakin membuat diri mereka terlantar dan tidak memiliki tujuan hidup yang jelas. Agar pemuda bisa bertanggungjawab dalam menjalani hidupnya diperlukan kesempatan untuk mengembangkan potensi yang dimiliki baik secara fisik, mental, sosial, dan ekonomi. Namun, kenyataan masih menunjukkan banyaknya pemuda yang mengalami hambatan dalam mencapai perkembangan diri sehingga memerlukan pelayanan secara khusus. Untuk mengurangi hal tersebut, pemerintah melakukan upaya untuk membantu mensejahterakan masyarakat (Asep, Wawancara, Cirebon, Januari 2019). 
Upaya pemerintah dalam membangun kesejahteraan sosial diwujudkan melalui program Pelayanan Rehabilitasi Sosial. Rehabilitasi sosial ditujukan untuk masyarakat yang mengalami disfungsi sosial seperti gelandangan dan pengemis anak. Faktor dari disfungsi sosial, antara lain kemiskinan, kacacatan, keterlantaran, ketunaan sosial, korban bencana dan pengungsi, keterpencilan, eksploitasi, korban tindak kekerasan, dan disentegrasi. Terkait hal itu, pemerintah berkewajiban membangun kesejahteraan, yaitu dengan adanya sistem panti rehabilitasi sosial (Peraturan Kementrian Sosial UU No 11 Tahun 2009 Tentang Kesejahteraan Sosial Pasal 7).

Pemuda yang mengalami disfungsi sosial sebenarnya diciptakan oleh Allah dengan memiliki potensi dan mampu memecahkan masalah dalam hidupnya. Berdasarkan pendekatan eksisitensial-humanistik, manusia memiliki potensi untuk memilih dan membuat keputusan bagi diri sendiri dan lingkungannya (Lubis, 2011, hlm. 153-154). Di sisi lain, menurut konsep konseling, manusia adalah makhluk biologi, pribadi, sosial dan religius. Berdasarkan hakikat manusia tersebut, manusia sebagai makhluk pribadi memiliki potensi akal untuk berpikir rasional dan mampu menjadi hidup sehat, kreatif, produktif serta efektif (Anwar, 2014, hlm. 80). Manusia merupakan makhluk yang spesial yang memiliki potensi akal untuk mengarahkan hidupnya ke arah lebih baik. Hal itu diperkuat oleh firman Allah "Ketahuilah bahwa Allah yang menghidupkan bumi setelah matinya (kering). Sungguh, telah kami jelaskan kepadamu tanda-tanda (kebesaran Kami) agar kamu mengerti” (Q.S. Al-Hadid: 17). Ayat tersebut menjelaskan agar kita tidak berputus asa apabila dihadapkan pada kesulitan dan harus yakin pada pertolongan Allah.

Para pemuda yang hidup di jalanan sebenarnya masih sanggup untuk berkarya dan bekerja. Namun, keterbatasan pengetahuan dan berbagai problematika membuatnya menjalani kehidupan yang tidak layak di jalanan. Maka dari itu, di unit-unit rehabilitasi terdapat layanan rehabilitasi sosial untuk memulihkan kondisi psikis klien dalam menghadapi permasalahan pada potensi dirinya yang menyangkut keberlangsungan hidupnya di masa depan. Hal ini selaras dengan pernyataan Willis (2014, hlm. 65) bahwa beberapa layanan yang terdapat di rehabilitas, yakni bimbingan sosial, rohani, keterampilan, dan lainnya.

Adapun sasaran pengembangan potensi dan keterampilan di Bina Mandiri Palimanan Cirebon adalah orang-orang yang berusia produktif sekira 18-40 tahun atau lulusan dari Sekolah Tingkat Atas yang belum memiliki pekerjaan (Asep, Wawancara, Cirebon, November 2019). Selain pemuda yang baru lulus sekolah, di satuan itu terdapat anak jalanan yang terjaring razia Polisi Satuan Pamong Praja sewilayah Provinsi. Anak jalanan tersebut dibina dan direhab dengan diberikan bimbingan keterampilan dalam berbagai bidang. Usia produktif tersebut dimanfaatkan untuk mengembangkan potensi yang dimiliki agar individu mampu menjalani kehidupan yang layak dan dapat diterima oleh masyarakat (Asep, wawancara Cirebon, 17 November 2019). Dengan adanya pelatihan diharapkan dapat mencegah timbulnya permasalahan yang berkaitan dengan upaya mencari pekerjaan. 


\section{PEMBAHASAN}

\section{A. Proses Layanan Rehabilitasi Sosial dalam Pembimbingan Karir Klien Binaan}

Proses layanan rehabilitasi sosial merupakan salah satu kebijakan yang mengatur tentang kesejahteraan sosial. Layanan tersebut berguna bagi mereka yang memiliki masalah dalam dirinya. Pelayanan rehabilitasi sosial diberikan kepada klien binaan terutama anak jalanan atau individu yang rentan hidup di jalanan. Tujuannya agar individu mampu mengembangkan potensinya dan mampu menyelesaikan permasalahan yang dihadapinya secara mandiri (Soetomo, 2015, hlm. 224-228). Tujuan lainnya agar mereka mampu mengembangkan diri dalam hal karier karena pada usia 15-24 tahun merupakan tahap eksplorasi (Super dalam Muawwanah, dkk., 2012, hlm. 34). Pada tahap ini mereka memikirkan berbagai alternatif jabatan, tetapi belum mengambil keputusan yang mengikat. Oleh karena itu, individu yang hidup di jalanan atau rentan hidup di jalanan memerlukan pendampingan. Salah satunya melalui pemberian pelayanan rehabilitasi sosial. Sekait itu, di Bina Mandiri Palimanan usia klien berkisar 15-21. Di usia produktif tersebut, mereka masih memiliki semangat dan masih bisa produktif. Oleh karena itu, diharapkan klien binaan ini memiliki pengalaman dan mampu mengembangkan potensinya (Asep, wawancara Cirebon, 17 November 2019).

Adapun proses awal Layanan Rehabilitasi Sosial dalam Pembimbingan Karier di Bina Mandiri Palimanan Cirebon melaui lima tahapan yang dijabarkan, sebagai berikut.

1. Sosialisasi dan Konsultasi

Layanan rehabilitasi sosial pada pendekatan awal dimulai dengan menentukan daerah yang rawan anak jalanan dan kerjasama dengan Dinas Sosial Kabupaten. Kerjasama itu untuk mensosialasikan kepada klien di Dinas Sosial mengenai layanan yang akan diberikan oleh Bina Mandiri Palimanan Cirebon. Adapun Dinas Kabupaten yang bekerjsama dengan Satuan Pelayanan Rehabilitasi Sosial ini diantaranya Dinas Sosial Kabupaten Garut, Kota Bandung, Kabupaten Subang, Kabupaten Cirebon, Kabupaten Sukabumi, Kabupaten Majalengka, Kabupaten Purwakarta, Kabupaten Karawang, Kabupaten Cianjur, dan Kabupaten Indramayu. Setiap Kabupaten merekomendasikan lima orang klien sehingga per angkatan totalnya 50 klien.

2. Identifikasi

Identifikasi ini dilakukan untuk menentukan daerah yang rawan terhadap anakanak yang rentan hidup dijalanan. Pada tahap ini pekerja sosial melakukan konsultasi dengan Dinas Sosial Kota yang menjadi sasaran. Kemudian mendapatkan data-data anak yang rentan hidup di jalanan.

3. Motivasi

Motivasi dan diagonisis yang dilakukan di Sub Unit Balai Rehabilitasi Sosial Bina Mandiri Palimanan dilakukan dengan pemberian penyuluhan dan motivasi yang diberikan oleh Pekerja Sosial kepada Klien Binaan. Motivasi diberikan agar 
klien dapat bangkit dan semangat dalam menjalani proses rehabilitasi sosial selama 4 bulan.

4. Seleksi dan Penerimaan

Seleksi dan perekrutan klien binaan yang dilakukan di Bina Mandiri Palimanan Cirebon sesuai dengan syarat. Jika memenuhi syarat, maka dilanjut dengan tahap penerimaan.

5. Asesment

Saat klien binaan sudah diterima dan memenuhi syarat untuk direhabilitasi, maka dilakukan asesment atau penggalian data. Penggalian data ini dilakukan dengan wawancara menanyakan mengenai identitas klien binaan. Wawancara dilakukan oleh Pekerja Sosial untuk mendapatkan data mengenai klien. Wawancara dilakukan dengan teknik pendekatan individu.

\section{B. Pelaksanaan Rehabilitasi Sosial dalam Membimbing Karir Klien Binaan}

Pelaksanaan rehabilitasi sosial, yaitu proses berlangsungnya pemberian layanan pemulihan kepada klien binaan. Pelaksanaan rehabiliitasi sosial terdiri dari asesment atau pengungkapan dan pemahaman masalah, pemberian beberapa bimbingan. Pengungkapan dan pemahaman masalah, yaitu kegiatan pengumpulan, menganalisis, merumuskan masalah, kebutuhan, potensi dan sumber yang dapat dimanfaatkan dalam pelayanan rehabilitasi sosial. Berikut tahapan dalam pelaksanaan rehabilitasi sosial dalam pembimbingan karir klien binaan di Satuan Pelayanan Rehabilitasi Sosial Bina Mandiri Palimanan Cirebon. Hal ini juga sesuai dengan acuan bimbingan karir menurut Zunker (dalam Hartono, 2016, hlm. 35-36).

\section{Pengukuran Kebutuhan}

Asesmen adalah kegiatan yang dilakukan untuk mengidentifikasi kebutuhankebutuhan klien tentang pelayanan bimbingan karier. Kebutuhan ini diantaranya: kebutuhan pengenalan bakat, minat, jenis pekerjaan, karakteristik pekerjaan, kompensasi dari pekerjaan dan kebutuhan lainnya. Di Bina Mandiri Palimanan Cirebon, klien diasesmen terlebih dahulu sebelum melakukan bimbingan karier. Tujuannya untuk memperoleh data mengenai diri pribadi klien (Asep, wawancara Cirebon, 10 Oktober 2019). Pengukuran kebutuhan (asesment of needs) yang dilakukan oleh pekerja sosial di Bina Mandiri Palimanan mencakup pendataan dan pengidentifikasian mengenai aspek fisik, medik / kesehatan, mental / psikologi, sosial, pendidikan dan vokasional / keterampilan.

\section{Orientasi}

Orientasi merupakan kegiatan untuk membantu klien dalam memahami lingkungan baru yang dimasukinya, dengan tujuan agar konseli memperoleh pemahaman sebagai modal penyesuaian diri pada lingkungan baru tersebut. (Walgito, 2010, hlm. 16) Orientasi yang dilakukan di Bina Mandiri Palimanan Cirebon kepada klien, yakni memperkenalkan klien kepada setiap orang atau 
petugas yang berada di lingkungan satuan tersebut. Setelah itu, klien binaan diajak melihat setiap ruangan dan fasilitasi yang ada di Bina Mandiri Palimanan Cirebon (Asep, Wawancara, Cirebon, 10 Oktober 2019).

\section{Kegiatan Individual}

Masing-masing konseli perlu mengikuti kegiatan individual yang dibutuhkannya. Kegiatan ini untuk memenuhi kebutuhan klien seperti: konsultasi hasil tes minat dan bakat, konsultasi hasil pengisian inventori tugas perkembangan dan kegiatan individual lainnya. Kegiatan indvidual di Bina Mandiri Palimanan Cirebon ditempuh dengan wawancara antara pekerja sosial dan klien untuk mengenal lebih dalam dan memperoleh data mengani minat dan bakat yang dimiliki oleh klien (Asep, Wawancara, Cirebon Maret 2019).

\section{Intervensi}

Kegiatan ini berupa konseling karier yang diberikan kepada klien secara individual atau kelompok. Di sini, konseli ikut terlibat aktif dalam menyelesaikan permasalahan karier klien dengan tujuan membantu konseli dalam mengentaskan masalah yang dihadapinya. Setelah melakukan wawancara, pekerja sosial di Bina Mandiri Palimanan Cirebon memberikan pelayanan yang sesuai dengan kebutuhan klien dan memfasilitasi hal yang klien butuhkan dalam mengembangkan potensi dirinya. Jika ada yang membutuhkan penanganan khusus mengenai psikisnya, maka pekerja sosial akan bekerjasama dengan psikolog agar mendapatkan penanganan yang tepat. (Asep, Wawancara Cirebon, 17 November 2019). Mengenai intervensi ini terdapat beberapa layanan yang bisa diberikan kepada klien diantaranya sebagai berikut.

a. Perawatan dan pengasuhan, yaitu upaya untuk menjaga, melindungi dan mengasuh agar dapat melaksanakan fungsi sosialnya. Perawatan dan pengasuhan di Sub Unit Balai Rehabilitasi Sosial dilakukan dengan penerimaan klien binaan untuk tinggal di Bina Mandiri Palimanan selama 4 bulan. Setiap harinya klien difasilitasi tempat tinggal beserta perlengkapan sehari-hari seperti kasur, pakaian seragam, peralatan mandi bahkan uang saku setiap harinya yang berjumlah Rp.7.500/hari dan diberikan makan 3kali/hari (Suci, dkk., 2017, hlm. 234).

b. Pelatihan vokasional dan pembinaan kewirausahaan merupakan usaha pemberian keterampilan kepada penerima layanan agar mampu hidup mandiri dan produktif. Proses layanan rehabilitasi sosial dalam membimbingan karier yang dilakukan di Bina Mandiri Palimanan Cirebon diberikan dalam bentuk bimbingan vokasional. Pelatihan tersebut diberikan kepada klien dengan memberikan teori dan praktik. Misalnys, menjahit, otomotif, elektronik dan gawai.

c. Bimbingan mental spritual, yaitu kegiatan yang dilakukan untuk meningkatkan pengetahuan serta memperbaiki sikap dan perilaku berdasarkan ajaran agama (Nurhayati, 2016, hlm. 67). Bimbingan mental yang dilakukan di Satuan

Pelayanan Rehabilitasi Sosial Bina Mandiri Palimanan ini dilakukan dengan 
pemberian penyuluhan dari Kepolisisan setempat mengenai kedisiplinan dan pengembangan mental. Selain diberikan penyuluhan klien juga diberikan pengetahuan mengenai Praktik Baris Berbaris. Lalu, bimbingan mental dan spritual yang dilakukan di Bina Mandiri Palimanan, yaitu dengan pemberian pengetahuan mengenai pendidikan agama diantaranya terdapat pembelajaran praktik salat dan mengaji yang dilakukan setiap Senin pukul 05.00-06.30. Selain itu juga terdapat kegiatan rohani pembacaan Surat Yasin dan ceramah yang dilaksanakan setiap Kamis pukul 19.00-20.00. Tujuan dari kegiatan tersebut adalah untuk pemberian pemahaman mengenai agama kepada klien menuju kehidupan yang sesuai dengan norma agama maupun masyarakat.

d. Pembinaan fisik merupakan kegiatan untuk memelihara dan meningkatkan kesehatan fisik jasmani penerima pelayanan. Di Bina Mandiri Palimanan klien binaan medapatkan jadwal dalam setiap minggunya. Olahraga biasa dilakukan di Jumat pukul 08.00-10.00. Bimbingan sosial dan konseling psikososial, yaitu semua bentuk pelayanan bantuan psikologis yang ditujukan untuk mengatasi masalah psikososial agar dapat meningkatkan keberfungsian sosial. Pelayanan tersebut berbentuk pemberian pengetahuan mengenai etika dan budi pekerti yang sesuai dengan norma masyarakat. Bimbingan sosial ini diberikan oleh Pekerja Sosial. Selain itu, memberikan juga pemahaman kepada klien mengenai tugasnya di lingkungan masyarakat. Konseling psikososial diberikan jika klien mengalami masalah yang sekiranya membutuhkan penanganan agar dapat menjalani kehidupan dengan lebih baik. Namun, di Satuan Pelayanan Balai Rehabilitasi Sosial Bina Mandiri Palimanan dalam pemberian konseling psikososial masih kurang karena kurangnya kesadaran klien binaan terhadap masalah yang ia alami.

e. Pelayanan aksesibilitas, yaitu penyedian kemudahan bagi penerima pelayanan guna mewujudkan kesamaan hak dan kesempatan dalam segala aspek kehidupan. Di Bina Mandiri Palimanan diberikan dalam bentuk pemberian makan sehari tiga kali, uang saku setiap harinya, peralatan mandi, fasilitas olahraga, transportasi saat akan ke Rumah Rehabilitasi, dan Wi-Fi. Klien binaan di Bina Mandiri Palimanan setiap di akhir masa rehabilitasinya akan mendapatkan bantuan berupa alat keterampilan sesuai yang klien pelajari. Diantaranya bagi yang mengambil keterampilan menjahit akan diberikan alat jahit. Bagi yang keterampilannya otomotif, maka diberikan alat bengkel seperti kompressor dan bagi yang mengambil keterampilan elektro dan gawai, maka diberi alatnya seperti blower suplay, dan yang lainnya. (Arif dan Wawan, Wawancara, Cirebon, tanggal 17 Oktober dan 23 Oktober 2019).

f. Pelaksanaan Praktek Kerja Lapangan (PKL). Setelah klien binaan melakukan beberapa bimbingan terutama bimbingan keterampilan, maka ada waktu satu bulan klien binaan diberi kesempatan untuk mempraktekkan ilmu yang telah didapat di perusahan yang telah bekerjasama dengan Bina Mandiri Palimanan 
Cirebon. Adapun tempat perusahaannya diantaranya bengkerl Berkah Motor, Citra Mandiri Motor, Damai Jaya Motor, Ness Motor, Vinni Motor, An-Nur Motor, Sumber Rezeki Moto. Bagi yang menjahit, yaitu di Fadillah Konveksi dan Saidah Konveksi, sedangkan yang elektro di Raffi Eleketro dan Sinar Elektro. Pelaksanaan Praktek Kerja Lapangan (PKL) ini klien diberikan fasilitas oleh Bina Mandiri Palimanan Cirebon dengan diberikan bantuan antar jemput dengan angkot saat akan pergi dan pulang ke lokasi PKL. Selama PKL juga klien binaan akan dinilai mengenai pekerjaannya dilihat dari aspek kinerja, kebersihan, kerjasama, kecakapan, kemampuan dan kejujuran dan itu semua nanti sebagai bahan evaluasi pekerja sosial di Bina Mandiri Palimanan Cirebon (Hasil wawancara dengan Pak Asep, 23 Maret 2019).

\section{Bantuan Internet}

Bantuan internet dimaksudkan untuk memenuhi ketersedian informasi karier secara cepat melalui laman yang dapat diakses oleh konseli kapan dan di mana saja. Dari beberapa klien binaan, setiap klien memiliki pengalaman karier sendiri saat sebelum direhabilitasi. Tujuan kebanyakan dari klien binaan mengikuti kegiatan ini agar mendapatkan pengetahuan dan pengalaman sehingga hidupnya lebih baik lagi. Bantuan-bantuan strategis memang diperlukan agar individu mampu memahami akan dirinya dan mampu merencenakan masa depannya yang lebih baik (Hartono, 2016, hlm. 30).

\section{Hasil dari Rehabilitasi Sosial terhadap Karir Klien Binaan}

Setelah klien binaan diberikan bimbingan di Bina Mandiri Palimanan Cirebon klien mengalami beberapa perubahan baik dalam segi perilaku, norma, maupun keterampilan. Dari rangkaian proses rehabilitasi sosial yang sangat berpengaruh terhadap perkembangan karier klien adalah dalam proses bimbingan vokasional.

Hasil dari rehabilitasi sosial terhadap karier klien diantaranya mereka memiliki pengetahuan mengenai bidang keterampilan yang diikuti. Selain itu, klien menjadi lebih produktif. Klien yang telah direhab tentunya akan mengalami perubahan,minimal dalam pengetahuannya. Dalam pelayanan rehabilitasi sosial, terdapat layanan pelatihan vokasional yang mendorong klien memiliki keterampilan tertentu untuk mendapatkan pekerjaan yang layak agar diterima oleh masyarakat. Ada beberapa klien binaan yang sudah mendapatkan bimbingan dari Bina Mandiri Palimanan Cirebon dan mendapatkan pekerjaan yang lebih baik. Sebenarnya, dalam proses layanan rehabilitasi sosial terdapat layanan bimbingan lanjut. Bimbingan lanjut ini dilakukan oleh pekerja sosial yang mana dilakukan dengan cara mengunjungi daerah asal klien binaan dengan menghubungi pihak Dinas Sosial Kabupaten setempat. Lalu, mengunjungi kantor kecamatan dan sampai akhirnya ke desa asal klien yang akan dituju.

Hal tersebut dilakukan untuk menanyakan kabar dan mengetahui keadaan klien setelah diberikan layanan rehabilitasi sosial. Berdasarkan dari bimbingan lanjut tersebut 
akan diperoleh data mengenai klien yang sudah bekerja atau belum setelah mendapatkan pelayanan rehabilitasi sosial. Namun, sudah beberapa tahun akhir ini bimbingan lanjut di Bina Mandiri Palimanan Cirebon kurang berjalan. Pekerja sosial mendapatkan informasi data atau kabar hanya melalui komunikasi antar pribadi lewat gawai (Asep dan Diah, Wawancara, 05 April 2019).

Diantara klien yang sudah mendapatkan pekerjaan setelah mendapatkan layanan rehabilitasi sosial bimbingan keterampilan, yaitu IG. IG terakhir bersilaturahmi mengunjungi Bina Mandiri Palimanan Cirebon. IG memberikan kabar baik mengenai dirinya yang sudah bekerja. Selain itu, ada klien lain yang asal Cirebon yang sudah membuka usaha bengkel sendiri. Ada juga klien yang sudah mendapatkan pekerjaan yang lebih baik di luar kota. Hasil dari layanan rehabilitasi sosial terhadap karier tiga klien binaan berdasarkan capaian yang dibuat oleh Bina Mandiri Palimanan dapat dilihat dari aspek keterampilan dan semangat kerja yang terdiri dari beberapa indikator diantaranya yaitu :1) Penguasaan keterampilan, 2) Kesungguhan mengikuti keterampilan kerja, 3) Dorongan dan semangat kerja, 4) Disiplin kerja, 5) Tanggung jawab kerja, 6) Produktivitas kerja , 7) Kualitas pekerjaan, 8) Kerapihan Kerja.

Berdasarkan dari penelitian, penulis mendapatkan hasil bahwa dari proses layanan rehabilitasi sosial menghasilkan perubahan bagi diri klien binaan terutama dalam hal karier. Proses rehabilitasi sosial terhadap karier klien binaan di Bina Mandiri Palimanan Cirebon memberikan hasil yang memengaruhi perkembangan diri klien. Klien binaan menjadi lebih memahami tentang potensi, minat, dan bakat bahkan memiliki perencanaan hidup di masa depan.

\section{SIMPULAN}

Proses layanan rehabilitasi sosial dalam membimbing karir klien binaan di Bina Mandiri Palimanan Cirebon dilakukan dengan tiga tahap. Pada tahap awal terdiri dari beberapa proses, yaitu sosialisasi dan konsultasi dengan Dinas Sosial Kabupaten/ Kota yang menjadi sasaran dan bekerjasama dengan Bina Mandiri Palimanan Cirebon. Dilanjut dengan seleksi dan penerimaan. Lalu, di tahap pelaksanaan terdiri dari tahapan asesmen yang mencakup aspek fisik, kesehatan, mental, sosial, dan vokasional, intervensi (bimbingan mental, bimbingan spirtual, bimbingan fisik dan bimbingan keterampilan). Di tahap akhir ada tahap evaluasi dan tindak lanjut yang terdiri dari melakukan evaluasi terhadap layanan yang telah diberikan kepada klien binaan. Lalu, dilanjut dengan memberikan bimbingan lanjutan kepada klien. Hanya saja, pada tahap tersebut belum berjalan dengan aktif.

Adapun hasil layanan rehabilitasi sosial yang diberikan kepada klien binaan terutama anak jalanan ditujukan agar klien binaan dapat memperbaiki kehidupannya menjadi lebih baik dari aspek fisik, mental dan keterampilan. Dari aspek fisik klien binaan mendapatkan layanan kesehatan bagi yang memiliki gangguan kesehatan tertentu. Begitu pun dengan aspek mental, klien diberikan layanan psikologis bagi yang membutuhkan 
penanganan. Lalu, dalam aspek keterampilan klien binaan diberikan layanan bimbingan keterampilan yang terdiri dari menjahit, otomotif, dan elektro.

\section{DAFTAR PUSTAKA}

Anwar, M. F. (2014). Landasan Bimbingan Konseling Islam. Yogyakarta: Deepublish.

Hartono. (2016). Bimbingan Karier. Jakarta : Prenadamedia Group.

Lubis, N. L. (2014). Memahami Dasar-Dasar Konseling dalam Teori dan Praktik. Jakarta: Kencana Prenadamedia Group.

Mu'awwanah, E. \& Rifa H. (2012). Bimbingan Konseling Islam di Sekolah Dasar. Jakarta: Bumi Aksara.

Nurhayati, E. (2016). Bimbingan, Konseling \& Psikoterapi Inovatif. Yogyakarta : Pustaka Pelajar.

Suci, R.W., dkk. (2017). Proses Rehabilitasi Sosial Wanita Tuna Susila Balai Rehabilitasi Karya Wanita (BRSKW). Bandung : Universitas Padjadjaran.

Soetomo. (2015). Masalah Sosial dan Upaya Pemecahannya. Yogyakarta : Pustaka Pelajar.

Walgito, B. (2010). Bimbingan dan Konseling (Studi \& Karier). Yogyakarta : Andi.

Willis, S. S. (2014). Konseling Individual, Teori dan Praktek. Bandung : Alfabeta. 
176 | Ridwan \& Suteja - Proses Layanan Rehabilitasi ... 